\title{
FAKTOR-FAKTOR YANG MEMPENGARUHI PENGGUNAAN JAMU TRADISIONAL PADA IBU HAMIL UNTUK KESEHATAN IBU DAN ANAK DI WILAYAH PUSKESMAS KEMBARAN II BANYUMAS
}

\author{
Wilis Dwi Pangesti ${ }^{1}$ \\ Email: wilisdwi@gmail.com \\ Prodi Kebidanan DIII Fikes Universitas Muhammadiyah Purwokerto, J1. Soepardjo Roestam KM.7 \\ Sokaraja Purwokerto Jawa Tengah. Telp. (0281) 6448436
}

\begin{abstract}
Abstrak
Praktek penggunaan jamu tradisional dalam pemeliharaan kesehatan termasuk dalam masa kehamilan dan nifas di masyarakat merupakan budaya yang diwariskan secara turun menurun dari orang tua. Bidan sebagai tenaga kesehatan di masyarakat mempunyai tugas untuk melakukan promosi terkait penggunaan jamu tradisional yang bermafaat dan aman bagi kesehatan, serta mengedukasi untuk menghindari penggunaan jamu yang merugikan kesehatan. Penelitian ini bertujuan untuk mengetahui faktor-faktor yang mempengaruhi penggunaan jamu tradisional untuk kesehatan ibu dan anak. Metode penelitian yang digunakan adalah penelitian kualitatif dengan desain studi kasus. Partisipan diambil secara purposive, pada 6 orang partisipan primer dan 4 orang partisipan sekunder sebagai triangulasi. Analisis data menggunakan model analisis interaktif Miles dan Huberman. Berdasarkan penelitian didapatkan dua tema, yaitu terdapat faktor sosial dan faktor psikologis yang mempengaruhi penggunaan jamu tradisional untuk kesehatan ibu dan anak. Tema pertama tentang faktor sosial yang mempengaruhi penggunaan jamu tradisional terdiri dari: 1) Informasi penggunaan jamu tradisional merupakan informasi dan pengalaman turun menurun dari orang tua, 2) Dukungan dari suami dan keluarga, 3) Tersedianya penjual jamu gendong dan dukun bayi yang menyediakan jamu untuk masa nifas dan menyusui, dan 4) Informasi dari bidan tentang obat tradisional. Tema kedua tentang faktor psikologis yaitu adanya keyakinan dan kepercayaan pengggunaan jamu tradisional.
\end{abstract}

Kata Kunci: Faktor-faktor, Kesehatan ibu dan anak, Penggunaan jamu tradisional.

\section{Pendahuluan}

Kehamilan dan persalinan merupakan bagian dari proses kehidupan normal yang dialami semua wanita. Pada periode ini, wanita akan mengalami perubahan fisik untuk mendukung perkembangan janin dalam kandungannya, dan harus beradaptasi kembali ketika bayi sudah lahir. Wanita memerlukan asuhan yang berfokus pada dirinya dengan memperhatikan kebutuhan sebagai mahluk bio-psiko-sosial-spiritual dan kultural. Bidan sebagai tenaga kesehatan yang melakukan asuhan kepada wanita, harus mempertimbangkan aspek-aspek tersebut. Asuhan holistik yang diberikan bidan harus mencakup fisik-psikososial dengan mempertimbangkan spiritual dan kultural. Hal ini sesuai dengan filosofi bidan sebagai partner wanita sepanjang siklus hidupnya. ${ }^{(1)}$

Berdasarkan evidence based, asuhan kebidanan saat ini mulai mengkombinasikan pelayanan kebidanan konvensional dan komplementer. Hal ini sebenarnya tidak bertentangan dengan filosofi asuhan kebidanan yang memang mempertimbangkan aspek kultural. Selain itu, asuhan komplementer ini juga sejalan dengan kewenangan bidan untuk menghargai praktek budaya setempat dan edukasi obat tradisional/jamu yang aman selama siklus hidup wanita. ${ }^{\text {(2) (3) (4) }}$

Praktek budaya masyarakat dalam pemanfaatan bahan alam atau obat tradisional yang diwariskan secara turun menurun untuk pengobatan termasuk dalam masa kehamilan dan menyusui merupakan perilaku pemeliharaan kesehatan. Perilaku inidibentuk oleh tiga faktor, yaitu faktor predisposisi, faktor pemungkin dan faktor pendorong. Faktor prediposisi adalah faktor yang mempermudah dan mendasari terjadinya perilaku tertentu yang meliputi pendidikan formal, sikap, kepercayaan, keyakinan, nilai-nilai dan budaya. Faktor pemungkin adalah faktor yang memungkinkan untuk terjadinya perilaku tertentu, yang bisa 
berupa lingkungan fisik dan ketersediaan fasilitas dan sarana kesehatan.

Faktor pendorong adalah faktor yang memperkuat terjadinya perilaku, yang bisa berupa dukungan dari keluarga/kerabat, teman atau petugas kesehatan. Bidan sebagai tenaga kesehatan yang langsung berada di masyarakat memiliki tugas untuk promosi terkait penggunaan bahan alam/ jamu yang bermanfaat dan aman bagi kesehatan, serta edukasi untuk menghindari penggunaan bahan alam/jamu serta praktek budaya yang merugikan kesehatan. ${ }^{(5)}$

Berdasarkan hasil Riskesdas 2010 diketahui bahwa presentase penduduk yang berusia 15 tahun ke atas, terdapat $50 \%$ yang menggunakan jamu untuk pemeliharaan kesehatannya. Bentuk sediaan jamu yang diminum berupa kapsul/pil, seduh, rebusan dan cairan. Temuan ini mewakili seluruh wilayah di Indonesia, termasuk wilayah kecamatan Kembaran kabupaten Banyumas, Jawa Tengah. Selain itu, di wilayah Kabupaten Banyumas diketahui terdapat 90 tempat terapi komplementer yang mendukung pengobatan tradisional. ${ }^{(6)(7)}$

\section{Metode Penelitian}

Penelitian dilaksanakan di wilayah Puskesmas Kembaran II Banyumas, Jawa Tengah pada bulan September sampai dengan Desember 2017. Metode penelitian yang digunakan adalah penelitian kualitatif dengan desain penelitian studi kasus. Desain studi kasus ini medeskripsikan secara komprehensif aspek individu kelompok partisipan yaitu ibu-ibu hamil, baik primipara maupun multipara, dengan rentang usia reproduktif 20-35 tahun, dan tinggal di wilayah pedesaan. Peneliti melakukan pengkajian secara cermat kejadian, proses dan aktifitas partisipan. Partisipan primer pada penelitian ini terdiri dari 6 orang ibu hamil. Partisipan sekunder terdiri dari 2 orang bidan dan 2 orang orang tua ibu hamil sebagai triangulasi. Partisipan penelitian diambil secara purposive yang dilakukan secara sengaja mengacu pada syarat-syarat yang diperlukan. Data dalam penelitian ini merupakan data primer hasil wawancara dengan menggunakan pedoman wawancara. ${ }^{(8)}$
Analisis data menggunakan tehnis analisis kualitatif dengan model analisis interaktif dari Miles dan Huberman. Analisis terdiri dari reduksi data, sajian data, dan penarikan kesimpulan dengan proses pengumpulan data berbentuk siklus. Siklus dimulai dengan data yang terkumpul, direduksi, lalu peneliti menyajikan data tersebut, mengambil kesimpulan sementara untuk kemudian turun lagi ke lapangan. Kegiatan ini dilakukan sampai dengan peneliti yakin data telah jenuh dan dapat ditarik kesimpulan. Tahapan dalam analisis ini dimulai dengan tahapan reduksi data, yaitu merupakan proses seleksi, pemfokusan, penyederhanaan, mempertegas dan abstraksi data sehingga kesimpulan akhir dapat dilaksanakan. Tahap kedua adalah penyajian data, yaitu merangkai dan mengorganisasikan data. Tahap ketiga yaitu penarikan kesimpulan dengan cara memaknai informasi dengan melakukan pencatatan pernyataan, konfigurasi, arahan sebab akibat dan proposisi dari awal pengumpulan data. ${ }^{(9)}$

\section{Hasil dan Pembahasan}

Berdasarkan temuan pada penelitian ini, didapatkan dua tema, yang meliputi: 1) Faktor sosial yang mempengaruhi penggunaan jamu tradisional untuk kesehatan ibu dan anak; dan 2) Faktor Psikologis yang mempengaruhi penggunaan jamu tradisional untuk kesehatan ibu dan anak.

Tema pertama tentang faktor sosial yang mempengaruhi penggunaan jamu tradisional terdiri dari: 1) Informasi penggunaan jamu tradisional merupakan informasi dan pengalaman turun menurun dari orang tua, 2) Dukungan dari suami dan keluarga, 3) Tersedianya penjual jamu gendong dan dukun bayi yang menyediakan jamu untuk masa nifas dan menyusui, dan 4) Informasi dari bidan tentang obat tradisional. Tema kedua tentang faktor psikologis yaitu adanya keyakinan dan kepercayaan pengggunaan jamu tradisional. 
Faktor sosial yang mempengaruhi penggunaan jamu tradisional untuk kesehatan ibu dan anak

Berdasarkan hasil penelitian ini, ditemukan data dan informasi bahwa dalam penggunaan jamu tradisional untuk kesehatan ibu dan anak dipengaruhi adanya informasi penggunaan jamu tradisional secara turun menurun dari orang tua. Untuk memutuskan penggunaan jamu, partisipan selalu berdiskusi dengan suami dan keluarga. Dukungan dari suami, orang tua dan keluarga merupakan faktor penguat (reinforcing factor) penggunaan jamu ini.

Penelitian ini sejalan dengan penelitian sebelumnya, bahwa jamu dan obat tradisional merupakan tradisi turun menurun dari nenek moyang. Tradisi ini tetap berlanjut karena menunjukan bukti bermanfaat dan tidak menimbulkan efek samping. Di wilayah timur tengah, penggunaan obat tradisional bahkan digunakan untuk mengurangi keluhan pada masa kehamilan trimester awal. Berdasarkan evidence based, penggunaan jamu tradisional ini ternyata tidak memberikan pengaruh buruk terhadap kehamilan dan janinnya. (10) (11)

Informasi tentang penggunaan jamu tradisional untuk kesehatan ibu dan anak yang diperoleh secara turun menurun oleh masyarakat menjadi dasar pengetahuan dan sikap masyarakat untuk bertindak. Hal ini sejalan dengan penelitian penggunaan obat tradisional untuk pengobatan penyakit-penyakit di masyarakat yang secara signifikan dipengaruhi oleh pengetahuan dan sikap masyarakat. (12)

Penggunaan jamu tradisional oleh masyarakat ini juga dipengaruhi oleh masih tersedianya jasa pembuat dan penjual jamu tradisional di daerah. Selain itu, perawatan pada masa kehamilan sampai melahirkan di daerah juga masih tersedia jasa dukun bayi yang menyediakan jamu tradisional. Masyarakat masih mempercayai tradisi turun menurun ini, karena dirasa memberikan manfaat yang baik. Dukun bayi dan penjual jamu tradisional merupakan alternatif perawatan kesehatan yang dipilih karena kriteria kenyamanan dan kemudahan akses di masyarakat. Faktor biaya murah/ekonomi bukanlah faktor utama dalam menentukan penggunaan jamu tradisional ini. (7)

Adanya informasi dari bidan tentang jamu/obat tradisional juga menjadi faktor yang mempengaruhi penggunaan jamu tradisional ini. Partisipan menginformasikan bahwa mereka telah diberikan informasi seputar jamu tradisional yang boleh digunakan karena aman untuk kesehatannya dan jamu tradisional yang tidak boleh dikonsumsi karena merugikan kesehatan, terutama pada masa kehamilan sampai menyusui serta anak-anak. Hasil penelitian ini sejalan dengan penelitian sebelumnya yang menginformasikan penggunaan jamu/obat tradisional dalam perawatan kesehatan. Bahkan bidan memberikan pelayanan kesehatan dengan menggunakan jamu/obat tradisional berupa obat herbal/ramuan sebagai pelengkap obat konvensional sebanyak $11,5 \%$. $^{(2)}$

Faktor Psikologis yang mempengaruhi penggunaan jamu tradisional untuk kesehatan ibu dan anak

Penggunaan jamu tradisional untuk kesehatan ibu dan anak di masyarakat sangat dipengaruhi oleh keyakinan dan kepercayaan di masyarakat. Menurut Spranger dalam Notoatmojo (2003) menyebutkan bahwa kepercayaan atau keyakinan seseorang merupakan salah satu aspek pembentuk perilaku. Kepribadian seseorang ditentukan oleh salah satu nilai budaya yang dominan pada diri orang tersebut. Selanjutnya kepribadian akan menentukan pola dasar perilaku orang tersebut. Keyakinan dan kepercayaan wanita di masyarakat tentang penggunaan jamu tradisional merupakan hal yang turun menurun ditularkan pada masing-masing individu dengan pengaruh orang tua dan lingkungan. (5)

Kepercayaan dan keyakinan dapat didefinisikan sebagai sesuatu yang didengar atau apa yang ditemui tanpa harus berdasarkan penelitian terkini, atau bisa jadi berasal dari hasil pemikiran, tindakan, persepsi dan motivasi. Kepercayaan dan keyakinan seseorang terjadi karena informasi budaya yang diterima sejak lahir dan mempengaruhinya. Seseorang yang terlahir di lingkungan yang memiliki 
tradisi turun menurun, biasanya akan menganggap bahwa hal tersebut merupakan kebenaran yang harus diikuti. (13)

Penggunaan jamu tradisional di masyarakat merupakan tradisi turun menurun yang dipercaya bermanfaat bagi kesehatan ibu dan anak. Proses seseorang menggunakan jamu tradisional diawali dari penerimaan informasi, memproses informasi dengan mempertimbangkan dampak positif dan negatif, kemudian mencari dukungan dari keluarga atau lingkungan, untuk kemudian menggunakan jamu tradisional tersebut sebagai tindakan dari kepercayaannya. ${ }^{(5)}$

Kedua faktor yang mempengaruhi penggunaan jamu tradisional ini, baik sosial maupun psikologis, merupakan bagian dari perilaku pemeliharaan kesehatan di masyarakat. Secara umum, perilaku yang mendukung pemeliharaan kesehatan, merupakan hal yang harus dilestarikan. Praktek penggunaan jamu yang terintegrasi dengan pelayanan kesehatan sebenarnya telah diprogramkan sejak tahun 2007 oleh pemerintah. Selain itu, pemerintah juga telah memasukan pelayanan kesehatan tradisional sebagai bagian dari upaya penyelenggaraaan upaya kesehatan dengan memanfaatkan obat tradisional yang telah terbukti berkasiat dan aman untuk pencegahan, pengobatan, perawatan dan atau pemeliharaan kesehatan. (6) (14)

Bidan sebagai tenaga kesehatan yang berada di masyarakat dalam memberikan pelayanan kesehatan terutama pada ibu dan anak harus menghormati keberagaman budaya. Mengintergasikan praktek budaya tradisional yang terbukti berkhasiat dan aman bagi kesehatan ibu dan anak. Asuhan kebidanan yang diberikan merupakan asuhan yang holistik dan kontinu, didasarkan pada pemahaman tentang pengalaman sosial, emosional, budaya, spiritual, psikologi dan fisik ibu dan anak. Hal ini merupakan bagian dari filosofi asuhan kebidanan. Selain itu, model praktek bidan di masyarakat juga bertujuan untuk memberdayakan ibu agar bertanggung jawab atas kesehatan merekadan kesehatan keluarganya. ${ }^{(1)(15)}$

\section{Kesimpulan}

Penggunaan jamu tradisional untuk kesehatan ibu dan anak di wilayah Puskesmas Kembaran II dipengaruhi oleh dua faktor, yaitu faktor sosial dan psikologis. Faktor sosial dapat dijelaskan melalui temuan informasi dan pengalaman turun menurun dari orang tua, dukungan dari suami dan keluarga, tersedianya jasa dukun bayi dan penjual jamu yang menyediakan jamu tradisional dan informasi dari bidan tentang jamu tradisional yang aman bagi kesehatan. Faktor psikologi yang mempengaruhi penggunaan jamu tradisional adalah adanya keyakinan dan kepercayaan masarakat terhadap jamu tradisional yang berkhasiat dan aman.

\section{DaftarPustaka}

[1] PPIBI. 50 Tahun IBI Menyongsong Masa Depan. VII ed. Sofyan, editor. Jakarta: PPIBI; 2006.

[2] Kostania G. Pelaksanaan kebidanan komplementer pada bidan praktek mandiri di kabupaten klaten. GASTER. 2015 February; 12(1).

[3] Wiraharja RS, Heidy, Rustam S, Iskandar M. Kegunaan jahe untuk mengatasi gejala mual dalam kehamilan. Damianus Journal of medicine. 2011 Oktober; 10(3): p. 161-197.

[4] Setyawati N, Wahyuningsih MSH, Nurdianti DS. Pemberian jahe instan terhadap kejadian mual muntah dan asupan energi pada ibu hamil trimester pertama. Jurnal gizi klinik indonesia. 2014 April; 10(4): p. 191197.

[5] Notoatmojo S. Pendidikan dan perilaku kesehatan Jakarta: Rineka Cipta; 2003.

[6] Kemenkes. Riskesdas kementrian kesehatan. [Online].; 2013 [cited 2018 Januari. Available from: www.depkes.go.id.

[7] Kamaluddin R. Pertimbangan dan alasan pasien hipertensi menjalani terapi alternatif komplementer bekam di kabupaten banyumas. Jurnal keperawatan soedirman. 2010 Juli; 5(2): p. 95-104.

[8] Cresswell, W John. Research Design, Pendekatan penelitian kualitatif, 
kuantitatif, dan mixed Yogyakarta: Pustaka Pelajar; 2009.

[9] Moeleong L. Metodologi penelitian kualitatif, Edisi revisi Bandung: ROSDA; 2004.

[10] Pizzorno JE, Murry MT. Texbook of natural medicine USA British: Elsevier; 2013.

[11] John NJ, Shantakumari N. Herbal medicines use during pregnancy: A review from the middle east. Oman medical journal. 2015; 30(4).

[12] Astuti A. Tiga faktor penggunaan obat herbal hipertensi di kota jambi.
Journal Endurance. 2016 June; 1(2): p. 81-87.

[13] Dunkekley J. Health promotion in midwivery practice, A resource for health professionals British: Bailliere Tindall; 2005.

[14] Depkes. Undang-Undang Republik Indonesia Nomor 36 Tahun 2009 Kementrian Kesehatan. [Online].; 2009 [cited 2018 January. Available from: www.depkes.go.id.

[15] ICM. Phylosophy and model of care. [Online].; 2005 [cited 2018 January. Available from: www.internationalmidwives.org/. 